\title{
Sense of security in single women and women in lasting relationships
}

\section{BACKGROUND}

The modern preference for the independence of an individual and an individualistic attitude does not make for favourable conditions for the sense of security, a consequence of which may be the inability of an individual to build and sustain close emotional relationships with others. The sense of security, which is determined by a durable relationship and confidence in its future, is especially important for the health of an individual.

The goal of the current study was to assess the sense of security among women of different marital status (single, cohabiting and married). It was also investigated how the women assess their economic status and if it is correlated with their sense of security.

PARTICIPANTS AND PROCEDURE

Two hundred and forty women with secondary or higher education, aged between 24 and 35, took part in the study. Participants were divided into three groups: single ( 80 women), cohabiting (82 women) and married (78 women).

\section{RESULTS}

Sense of security differentiated single and married women only in the aspect of the sense of stability, whereas all of the other dimensions of the sense of safety differentiated married women and cohabiting women. Married women scored significantly higher. Economic status of the participants did not have an influence on their sense of security.

\section{CONCLUSIONS}

Treating a relationship as something temporary negatively influenced the sense of safety of cohabiting women. It is however impossible to exclude the possibility of a selection bias, where the women with a higher sense of safety have higher chances to form a legalized and stable relationship than women with a lower sense of security.

\section{KEY WORDS}

sense of security; economic status; singles; cohabiting; marriage 


\section{BACKGROUND}

Fulfilment of needs, including the especially important need for security, is a condition for the proper psychosocial functioning of an individual. The need for security is of central importance to the quality of an individual's functioning and fulfilment of one's developmental potential. It is the second need in Maslow's hierarchy, immediately after the physiological needs and before the needs for belongingness, love, respect and self-actualisation (Maslow, 1964, 1990; Nelicki, 1999). An individual who does not have a properly structured and relatively consistent view of the world cannot realize the needs for belongingness and love. If it nonetheless happens, it is an unconscious process, and the aforementioned needs are fulfilled in an ostensible and superficial way, constituting a means to provide an equally ostensible sense of security (Maslow, 1964, 1990).

Security is considered to be a sense of being liked, accepted and treated amicably. It is associated with perceiving belongingness - when an individual is aware of being in their own place, having an adequate position in the group. It is rarely associated with anxiety and threat. Individuals who have a sense of security perceive other people as friendly, benevolent and sincere. It is also accompanied by a lack of hostility as well as tolerance. Such individuals are usually open to the world and other people rather than being centred around themselves. Their relations with their social environment are warm. It lets them realistically cope in life, with relatively few neurotic or psychotic behaviours. Being deprived of the sense of security results in a different set of behaviours, and the perception of lack of acceptance, a sense of abandonment and disdain or hatred from the social environment. Such people do not feel loved; they feel they are being treated coldly and without sincerity. They experience loneliness, alienation, subjective isolation and anxiety. This stimulates negative attitudes towards the social environment, such as lack of trust, resentment and jealousy or even hostility towards others. Such a perception of the world may lead to egocentric and individualistic behaviours (Uchnast, 1990).

Steuden and Borczon (2002) characterise individuals with a high sense of security as trusting, self-confident, capable of undertaking and fulfilling tasks. Such individuals have learnt a positive scheme of behaviours from their family of origin, which is a base for building satisfying relationships. These features of the sense of security can let the individual fulfil even their highest standards with regards to their marriage. Individuals with a low sense of security do not exhibit such potentials. They usually tend to reduce their emotional deficits instead of building a bond with another person that is based on subjective and symmetrical relations.
The constellation of features associated with the fulfilment of the three basic needs - acceptance, security and belongingness - makes for a syndrome of sense of security. Thanks to it the secondary features - characterological attitudes and propensities towards relative behaviours - are formed and reinforced. According to Maslow, the syndrome of sense of security is a relatively firm attitude towards oneself and one's environment (Uchnast, 1990), which with time becomes independent of its sources. Maslow's idea assumes that the need for security has to be fulfilled during childhood, so that a relatively durable syndrome of security can be formed in adulthood, which does not mean that is not subject to change. New favourable interpersonal experiences, and especially close relations with other people, can contribute to an increase in the sense of security. These changes are possible because the syndrome of sense of security or lack thereof is understood as an ensemble of a dynamical character. It is however difficult to decrease or increase the levels of sense of security, since individuals tend to cling to one defined lifestyle. People tend to perceive the known as the only safe way. This is why they are afraid of change. Still, such changes may occur due to the systemic nature of the sense of security. Selected social relations may influence the levels of sense of security. Maslow (1986) used an example of a woman with a low sense of security, whose sense of security became higher after getting married. This was caused by a satisfying relationship giving her a sense of being important, valuable and worthy of love, which in turn improved her relations with other people. Therefore some non-arbitrary, long-term circumstances can lead to durable changes in one's structure of personality. A permanent change in one of the symptoms leads to changes in the other elements of the syndrome.

The level of sense of security may be a descriptor of the type of relations with others that is dependent on the levels of closeness of the partners. These can be superficial relations of colleagues, closer relations such as friendships, or very close, intimate relationships. Having a sense of safety as a base makes room for the development of a sense of belongingness and love. This can lead to the formation of long-term relationships. The need for security motivates an individual to seek a partner who they can rely on and who provides them with a sense of assurance and stability (even if only on the level of dreams and assumptions) (Garczyński, 1972). The sense of security is the most important for a relationship. At the same time legalisation of the relationship, due to the mutual safety, is the best option for the family. It is believed that a legalised relationship is a starting point for stability, a base on which the professional existence is built and social stress factors are limited (Meyer, 1993; Schneewind, 1999; Vaskovics, Rupp, \& Hofmann, 1997).
Sense of security in women 
Research shows that singles as well as cohabiting informal couples are characterised by high levels of anti-health behaviours (Robins \& Regier, 1991; Sampson \& Laub, 1990). They experience more stress and anxiety (Brown, 2000; Coombs, 1991; Mastekaasa, 2006), and manifest more functioning disorders and symptoms of depression (Janicka, 2012).

The current socio-economic conditions create and reinforce the sense of independence and individualistic attitudes among young adults. The aforementioned features limit the opportunities to give and receive social support, which is not without significance for the sense of security. As a consequence, an individual may become unable to form and maintain close emotional relationships with other people. The social changes are manifested in the number of divorces, informal couples and singles. Research shows that not only men, but also increasing numbers of women prefer informal relationships or being single (Janicka 2006, 2012; Kwak, 2005; Slany, 2006). It turns out that socially important and biologically determined female roles of a wife and mother are no longer a priority. Good education and better job opportunities give women a chance for economic independence and development in a career path, which often conflicts with undertaking the marital and parental roles (Jamieson et al., 2002; Platell, 2006; Schneer \& Reitman, 2002). Being a parent, especially, is currently not considered an inherent developmental task of early adulthood (Gurba, 2010; Nawe-Herz, 2002a). The procreative function is under more control, and is often deferred, because young adults are fulfilling their personal needs associated with their individual development first (which was true also for the group examined in the current study). In the 1990 s, mothers were more often women with primary or secondary education, whereas in 2011 most mothers (over 40\%) were those with higher education (Demographic Yearbook, 2012).

Since the 1970s there has been a rising tendency for informal relationships (cohabiting) or staying single, which came to Poland in the late 1990s. The highest index of cohabiting is observed in Norway, where about $90 \%$ of relationships are informal (Mortensen, Torsheim, Melkevik, \& Thuen, 2012). In the USA such couples represent about 60\% (Hsueh, Morrison, \& Doss, 2009). In Poland in 1974 the number of heterosexual partnerships was estimated to be about 90000 , which was only about $1 \%$ of all relationships in the country. Such relationships were first included in the census in 2002, and according to the data of the Main Statistical Office (Polish: Główny Urząd Statystyczny - GUS) there were 198000 informal relationships, and in 2011 this number reached 397000 (Demographic Yearbook, 2012). A 2013 survey by TNS Poland suggests that two-thirds of Poles support informal heterosexual relationships. A third of people in Poland are currently single. Taking into account the extended period of education and professional development that results in delayed independence and transition into adulthood, it can be assumed that, in line with the definition by Jaszewska (2006), a single is an individual between the ages of 25 and 55 who is financially independent, has no long-term partner and lives in their own household. Statistics show that in Poland being single is most popular between the ages of 25 and 29 (almost 50\%). About $30 \%$ of people are single between the ages of 30 and 34, 21-25\% between the ages of 35 and 55, and then the number increases again to $40 \%$ in the $56-$ 60 age group. Every fourth Pole between the ages of 24 and 34 is single (every third one in cities). The data of the Main Statistical Office indicate that the number of singles in Poland is currently about 7 million, but it is estimated to reach 10 million by 2035 (Demographic Yearbook, 2012).

The goal of the current study was to assess the sense of security among women of different marital status. The following research questions were formed:

1. Is there a difference in the sense of security and its dimensions between married, cohabiting and single women?

2. Is there a correlation between the marital status of the investigated women and their economic situation?

The author hypothesized that single women would exhibit a lower sense of security in comparison to those in long-term relationships (either married or cohabiting). The pursuit of security requires the acceptance of dependence in relations with others, which inherently limits the sense of independence that is associated with concentrating on oneself and one's own needs. Individuals exhibiting the need for independence are rarely a source of support and can rarely count on support from others. Research suggests that the form of relationship may be crucial to the sense of security. Cohabitation is characterized by lower mutual dependency and the associated lower sense of security in comparison to marriage (Cohan \& Kleinbaum, 2002; Janicka, 2008; Nave-Herz, 2002a; Hsueh et al., 2009; Rhoades, Stanley, \& Markman, 2012; Waite \& Joyner, 1999). Singles are also regarded as highly independent (Pillsworth $\&$ Haselton, 2005). They find it difficult to build relationships, as, according to Jaszewska, they are most interested in themselves. Their social relations are usually limited to their workplace and so-called impersonal, internet-based relations (DePaulo \& Morris, 2005a, 2005b).

Sense of safety is manifested through the pursuit of continuity and order, which concerns not only interpersonal relations, but also material standards. At the material level it is manifested in stockpiling, gathering wealth and financial security (Niemelä, 1997). The current study attempted to verify how the wom- 
en in the investigated group perceive their economic situation, and if it has an influence on their sense of security. Referring to previous research (Aronson \& Huston, 2004; Manning \& Lichter, 1996; Hirschl, Altobelli, \& Rank, 2003; Wilmoth \& Koso, 2002) it was hypothesised that economic situation may be a covariate of the sense of security and married women would assess it higher than those who are cohabiting or single.

\section{PARTICIPANTS AND PROCEDURE}

Two hundred and forty women in their early adulthood (aged between 24 and 35), students and professionals, participated in the study. All of the women were childless (though they declared the willingness to have a child after graduation), with secondary or higher education. They were part-time or postgraduate students. The participants were divided into three groups: singles (80 women), cohabitants (82 women) and married (78 women).

The minimal duration of a romantic relationship for women in both types of long-term relationships was one year. The recruitment of participants for the group of singles was in line with the Jaszewska (2006) and DePaulo and Morris (2005) criteria; therefore only women aged at least 25 , living in their own household and not involved in a stable sexual relationship in the previous 6 months, were included.

Women in the three groups were homogeneous in terms of age, which is shown in Table 1.

The author's survey and the Security-Insecurity Inventory (SII) of Uchnast were used in the study. The survey was developed by the author to meet the needs of the study, and it included questions concerned with demographics and economic conditions of the participants. The Security-Insecurity Inventory was used to assess the levels of sense of security. It is composed of 30 items selected from the 75-item version of the questionnaire by Maslow, adapted to Polish by Uchnast (1990). This psychometric test gives us four types of results: the general result for the sense of security (Ss) as well as results associated with the particular dimensions of the sense of security - i.e. the sense of intimacy - In (a determinant of the need for belongingness, love and closeness with others), stability - St (a determinant of the need of safe functioning in everyday life, having an influence on events, order), the sense of self-confidence - Sc (a determinant of the need for self-respect and self-affirmation).

In order to assess the reliability of SII, the internal consistency was measured for each of the items as well as for the whole set of the items, split-half reliability as well as the repeatability after a period of two weeks for a group of 75 students. In terms of repeatability, the reliability coefficients were as follows: Ss $-r=.93, \mathrm{In}-r=.89$, St $-r=.81$, Sc $r=.90$. In order to verify the validity, the results had to be compared with other similar psychometric methods - Polish adaptations of Shostrom's Personal Orientation Inventory (POI) and Catell's 16 Personality Factors Test (16-PF). The 16-PF scales explained $70 \%$ of the variability of the overall SSI score and $41 \%$ (In), $58 \%(\mathrm{St})$ and $62 \%(\mathrm{Sc})$ of particular aspects. The results obtained using SII are largely determined by varying structures of personality features, which are in line with Maslow's operating assumptions (Uchnast, 1990).

\section{RESULTS}

The sense of security and its aspects for the three groups of participants are presented in Table 2 and Table 3.

Singles and married women differed in only one dimension of the sense of safety - the sense of stability $(p=.022)$. Married women exhibited a significantly higher sense of stability (which determines the need for safe functioning in day-to-day life, influence over the course of events and order) in comparison to singles. The sense of safety differed between cohabiting and married women both in terms of the general score $(p=.002)$ and the particular dimensions: the sense of intimacy (which is associated with the sense of belongingness and love) $(p=.026)$, sense of stability and order $(p=.009)$, and self-confidence and self-respect $(p=.021)$. Married women were characterized by a significantly higher sense of safety than the cohabiting women. The social position of a married woman is assessed higher, which may result in the anxieties and insecurities of the cohabiting women. Cohabiting is regarded as a less stable and lasting type of relationship, in comparison to marriage (Binstock, 2003; Brown, 2003; Janicka, 2009; Kline et

Table 1

Age of participating women

\begin{tabular}{lllllll}
\hline Women & $n$ & Age & Mean & $S D$ & ANOVA $F$ & $p$ \\
\hline Single & 80 & $25-35$ & 28.70 & 3.70 & & \\
Cohabiting & 82 & $24-35$ & 27.90 & 3.30 & 27.20 & .216 \\
Married & 78 & $25-35$ & 29.10 & 3.90 & & \\
Total & 240 & $24-35$ & 28.50 & 4.20 & & \\
\hline
\end{tabular}


Table 2

Sense of security among single, cohabiting and married women

\begin{tabular}{|c|c|c|c|c|c|c|}
\hline Sense of security & Women & $n$ & Mean & $S D$ & ANOVA $F$ & $p$ \\
\hline \multirow{4}{*}{$\begin{array}{l}\text { Ss - sense of security } \\
\text { overall score }\end{array}$} & Single & 80 & 16.10 & 5.51 & 6.25 & .002 \\
\hline & Cohabiting & 82 & 14.60 & 5.41 & & \\
\hline & Married & 78 & 18.20 & 5.95 & & \\
\hline & Total & 240 & 16.30 & 5.79 & & \\
\hline \multirow{4}{*}{ In - sense of intimacy } & Single & 80 & 6.80 & 1.93 & 3.53 & .031 \\
\hline & Cohabiting & 82 & 6.50 & 1.99 & & \\
\hline & Married & 78 & 7.40 & 2.13 & & \\
\hline & Total & 240 & 6.90 & 2.05 & & \\
\hline \multirow{4}{*}{ ST - sense of stability } & Single & 80 & 4.40 & 2.27 & 5.38 & .005 \\
\hline & Cohabiting & 82 & 4.30 & 2.53 & & \\
\hline & Married & 78 & 5.60 & 2.64 & & \\
\hline & Total & 240 & 4.80 & 2.54 & & \\
\hline \multirow{4}{*}{$\begin{array}{l}\text { Sc - sense } \\
\text { of self-confidence }\end{array}$} & Single & 80 & 5.00 & 2.77 & 4.15 & .017 \\
\hline & Cohabiting & 82 & 3.90 & 2.64 & & \\
\hline & Married & 78 & 5.20 & 2.52 & & \\
\hline & Total & 240 & 4.70 & 2.69 & & \\
\hline
\end{tabular}

Table 3

Sense of security among single, cohabiting and married women - multiple comparisons using Tukey's HSD test

\begin{tabular}{lccc}
\hline Sense of security & Marital status & Marital status & Significance \\
\hline Ss - sense of security overall score & Single & Cohabiting & .297 \\
& Cohabiting & Married & .108 \\
In - sense of intimacy & Single & Cohabiting & .002 \\
& Cohabiting & Married & .218 \\
ST - sense of stability & Single & Cohabiting & .026 \\
Sc - sense of self-confidence & Cohabiting & Married & .022 \\
& & Married & .009 \\
& Cohingle & Mabiting & .067 \\
\hline
\end{tabular}

al., 2004; Nave-Herz 2002a, 2002b; Selzer, 2000; Waite \& Joyner, 1999). The chances for the legalization of the relationship usually diminish with the duration of cohabiting (Stanley, Rhoades, Amato, Markman, \& Johnson, 2010). Moreover, those remaining in informal relationships usually express lower interest in marriage than before entering the cohabitation, which is the case especially for men (Rhoades et al., 2006, 2012; Lichner \& Qian, 2008).

The sense of safety among young adults is often associated with financial security. This is why the author investigated how the women perceived their 
Table 4

Marital status of participants and their economic conditions

\begin{tabular}{|c|c|c|c|c|c|c|c|c|}
\hline \multirow{3}{*}{$\begin{array}{l}\text { Economic } \\
\text { conditions }\end{array}$} & \multicolumn{6}{|c|}{ Women } & \multicolumn{2}{|c|}{ Total } \\
\hline & \multicolumn{2}{|c|}{ Single } & \multicolumn{2}{|c|}{ Cohabiting } & \multicolumn{2}{|c|}{ Married } & \multirow[b]{2}{*}{$n$} & \multirow[b]{2}{*}{$\%$} \\
\hline & $n$ & $\%$ & $n$ & $\%$ & $n$ & $\%$ & & \\
\hline Good & 28 & 35.00 & 31 & 37.80 & 32 & 41.10 & 91 & 38.00 \\
\hline Average & 42 & 52.50 & 39 & 47.60 & 34 & 43.50 & 115 & 48.40 \\
\hline Bad & 10 & 12.50 & 12 & 14.60 & 12 & 15.40 & 34 & 12.80 \\
\hline Total & 80 & 100.00 & 82 & 100.00 & 78 & 100.00 & 240 & 100.00 \\
\hline
\end{tabular}

Note. $\chi^{2}=1.28, p=.903$

Sense of security in women economic situation. The results suggested that economic conditions do not differentiate the sense of safety of the participants $(F=2.46 ; p=.682)$. Further analyses revealed that most of the married women, cohabiting women, and singles assessed their situation as average (Table 4). No relationship was found between the marital status and economic status of women $\left(\chi^{2}=1.28, p=.903\right)$.

\section{DISCUSSION}

The presented results suggest significant differences in the sense of security among women of different marital status. Married women were characterized by higher levels of sense of safety than cohabiting or single women. The hypothesis that single women would be characterized by lower sense of security than women in long-term relationships (cohabiting and married) was not confirmed. The differences were observed only between married women and singles. Lower sense of security in the aspect of stability, which is characteristic for singles, as was confirmed by the current study, undoubtedly also limits their social predispositions, and it is only a question of the interpretation for the singles themselves if they prefer to perceive themselves as having limited chances for a relationship or rejecting the opportunities for forming relationships - being single by choice. It is of no significance, since the sense of security is shaped as a result of interpersonal relations and influenced by the opinions of others. Previous research has shown that singles are rejected, shamed and even discriminated against, both in the interpersonal aspects (preference for couples) and in the professional sphere (lower salaries) (De Paulo, 2006; DePaulo $\&$ Morris, 2005a). They are perceived (by both men and women of varying marital status) as less warm, less caring, with less social competences and lower satisfaction with life (Greitemeyer, 2009; Hertel, Schütz, DePaulo, Morris, \& Stucke, 2007; Szymanowicz \& Furnham, 2011). This is why singles pursue the change of their marital status the most, followed by people in informal relationships, whereas married individuals seek it the least (Greitemeyer, 2009). At the same time, singles can see both the advantages of their status, such as independence, privacy and more free time, and disadvantages, such as lack of security or the threat of loneliness (Żurek, 2008).

A stronger differentiation in terms of the sense of security was observed between married and cohabiting women. The general score, as well as scores across all of the aspects, turned out to be significantly higher among married women. The fact that bigger differences were observed between married and cohabiting women than between married and single women may be a result of the unclear position of the cohabiting women. Their status is unsure - it is in between being single and married. Previous research shows that most women prefer legalised relationships, treating cohabiting as a transition period intended to lead to marriage (Huang, Smock, Manning, \& Bergstrom-Lynch, 2011; Janicka, 2011). Temporary treatment of a relationship, applicable to cohabiting, has a negative influence on the sense of safety, especially that of women (Hohenester, 2000; Janicka, 2006; Kotlarska-Michalska, 1997a; Kwak, 1994; Meyer, 1993; Vaskovics et al., 1997). Research by Hsueh et al. (2009) showed that cohabiting individuals experience problems associated with sense of security and attachment more frequently than married individuals. According to Rogers (1995), the sense of safety is guaranteed only by a stable relationship such as marriage. Also Niemelä (1997) believes that the sense of safety, at the level of interpersonal relations, manifests itself by high levels of engagement in the relationship and its legalisation. Research by Kotlarska-Michalska (1997a) suggests that the bond between an individual and their closest family is the main indicator of the sense of safety. This bond is especially strong in marriage, where it is the partner who is perceived as the main source of help and support in difficult situations - not the parents, friends or even one's own children. Maintaining order, according to Kotlarska-Michalska (1997b), requires succumbing to norms and rules regulating the functioning of a relationship. Undoubtedly, cohabiting partners are devoid of such a strong bond 
on the material and interpersonal level that is only guaranteed by an institutionalised relationship. Stanley et al. (2006) treat the security with regards to the future of a relationship as the type of security that is the most important for the health of the partners.

No correlation was observed in the current study between the marital status of the participants and their economic status, though previous research (Aronson \& Huston, 2004; Manning \& Lichter, 1996) suggests that people in legalized relationships are characterized by a better economic situation, and that lack of a relationship or the instability of a relationship weakens the productivity and the accumulation of wealth. The levels of wealth are $75 \%$ lower among individuals who never got married (single or cohabiting) (Wilmoth \& Koso, 2002). Previous research confirms that the long-term and forward-looking nature of marriage promotes generating income and the accumulation of wealth (Hirschl et al., 2003). In the current study the economic situation of the participants turned out to be of no importance to their sense of security, even though young adults tend to identify a good financial situation with personal security. Financial security is especially important for singles, which is why they often eliminate or limit competing systems of values. Steuden and Borczon (2002) claim that individuals with a low sense of security usually attempt to reduce their emotional deficits by strengthening their personal values and sense of self-worth. It can be manifested through e.g. overzealous care for one's own appearance, professional position, or pursuit of financial security. One can risk stating that good living conditions may serve as a compensation for unfulfilled psychological needs, including the need for security. An opposite mechanism may also occur where individuals hide their personal advantages in order to gain approval, friendship or love from others. Szymanowicz and Furnham (2011) reported that single women do not admit their high IQ in fear of lowering their chances for finding a partner.

\section{CONCLUSIONS}

The presented results proved that women in legalised relationships are characterised by a higher sense of security than those cohabiting or single. With no doubt, a durable and legalised relationship determines women's sense of security. It is however impossible to exclude the possibility of selection bias, where the people with a higher sense of security have higher chances for a durable relationship than those with a low sense of security. This is because the sense of security is a determinant of the quality of the psychosocial functioning of an individual, which also determines their potential for building durable and intimate relationships.

\section{REFERENCES}

Aronson, S. R., \& Huston, A. C. (2004). The mother - infant relationship in single, cohabiting, and married Families: A Case for Marriage? Journal of Family Psychology, 18, 5-18.

Binstock, G. (2003). Separations, reconcilations and living apart in cohabiting and marital Unions. Journal of Marriage and Family, 65, 432-443.

Brown, S. L. (2000). The Effect of union type on physiological well-being: Depression among cohabiters versus married. Journal of Health \& Social Behavior, 41, 241-255.

Brown, S. L. (2003). Relationship quality dynamics of cohabitating unions. Journal of Family Issues, 24, 583-601.

Cohan, C. L., \& Kleinbaum, S. (2002). Toward a greater understanding of the cohabitation effect: premarital cohabitation and marital communication. Journal of Marriage and the Family, 64, 180-192.

Coombs, R. (1991). Marital status and personal well-beinig: A literature review. Family Relations, 40, 97-102.

DePaulo, B. M. (2006). Singled out. New York, NY: St. Martin's Press.

DePaulo, M. B., \& Morris, W. L. (2005a). Singles in society and science. Psychological Inquiry, 16, 57-83.

DePaulo, M. B., \& Morris, W. L. (2005b). Should singles and the scholars who study them make their mark or stay in their place? Psychological Inquiry, 16, 142-149.

Garczyński, S. (1972). Potrzeby psychiczne. Niedosyt. Zaspokojenie [Psychological needs. Deficiency. Fulfillment]. Warszawa: Nasza Księgarnia.

Greitemeyer, T. (2009). Stereotypes of singles: Are singles what we think. European Journal of Social Psychology, 39, 368-383.

Gurba, E. (2010). Wczesna dorosłość [Early adulthood]. In: B. Harwas-Napierała, \& J. Trempała. Psychologia rozwoju cztowieka. Charakterystyka okresów życia [Psychology of human development. The characteristics of the periods of life] (pp. 202-233). Warszawa: PWN.

Hertel, J., Schütz, A., DePaulo, B., Morris, W. L., \& Stucke, T. S. (2007). Sie ist Single..., na und? Wie werden Singles im Vergleich zu verheirateten Personen wahrgenommen? [She's single, so what? How are singles perceived compared with people who are married?]. Zeitschrift für Familienforschung, 19, 139-158.

Hirschl, T. A., Altobelli, J., \& Rank, M. R. (2003). Does marriage increase the odds of affluence? Exploring the life course probabilities. Journal of Marriage and the Family, 65, 927-938.

Hohenester, B. (2000). Dyadische Einheit. Zur sozialen Konstitution der ehelich Beziehung. Konstanz: UVK Universitätsverlag Konstanz $\mathrm{GmbH}$. 
Hsueh, A. C., Morrison, K. R., \& Doss B. D. (2009). Qualitative reports of problems in cohabiting relationships: Comparisons to married and dating relationships. Journal of Family Psychology, 23, 236-246.

Huang, P. M., Smock, P. J., Manning, W. D., \& Bergstrom-Lynch, C. A. (2011). He says, she says: Gender and cohabitation. Journal of Family Issues, 32, 876-905.

Jamieson, L., Anderson, M., McCrone, D., Bechhofer, F., Steward, R., \& Li, Y. (2002). Cohabitation and commitment: Partnership plans of young men and women. Sociological Review, 50, 356-377.

Janicka, I. (2006). Kohabitacja a matżeństwo w perspektywie psychologicznej. Studium porównawcze [Cohabitation and marriage in a psychological perspective. Comparative study]. Łódź: Wydawnictwo UŁ.

Janicka, I. (2008). Dynamika związku a wzajemna zależność kohabitujących partnerów [The dynamics of the relationship and the mutual dependence of cohabiting partners]. In: M. Bogdanowicz, \& M. Lipowska (eds.), Rodzinne, edukacyjne i psychologiczne wyznaczniki rozwoju [Familial, educational and psychological determinants of development] (pp. 71-82). Kraków: Oficyna Wydawnicza Impuls.

Janicka, I. (2009). Ryzyko kryzysów i konfliktów z związkach kohabitacyjnych [The risk of crisis and conflicts in cohabiting-type relationships]. Przeglad Psychologiczny, 52, 293-308.

Janicka, I. (2011). Satisfaction with marriage in the case of prenuptially cohabitating and non-cohabitating couples. In: H. Liberska (ed.), Relations in Marriage and Family: Genesis, Quality and Development (pp. 51-65). Bydgoszcz: Wydawnictwo Uniwersytetu Kazimierza Wielkiego.

Janicka, I. (2012). Poczucie dobrostanu u osób poślubionych, kohabitujących i singli [Sense of wellbeing among married individuals, cohabiting individuals and singles]. In: T. Rostowska, \& A. Lewandowska-Walter (eds.), Matżeństwo i rodzicielstwo a zdrowie [Marriage and parenthood versus health] (pp. 26-53). Toruń: Wydawnictwo A. Marszałek.

Jaszewska, D. (2006). Single [Singles]. W drodze, 391, 3.

Kline, G. H., Stanley, S. M., Markman, H. J., Olmos-Gallo, P. A., St Peters, M., Whitton, S. W. \& Prado, L. M. (2004). Timing is everything. Pre-engagement cohabitation and increased risk for poor marital outcomes. Journal of Family Psychology, 18, 311-318.

Kotlarska-Michalska, A. (1997a). Stosunki międzyludzkie jako sfera bezpieczeństwa i zagrożenia [Interpersonal relations as a sphere of safety and threat]. In: A. Kotlarska-Michalska, T. Rusanen, \& P. Niemelä (eds.), Poczucie bezpieczeństwa spoŁecznego w świetle badań polsko-fińskich [Sense of social safety in the light of Polish-Finnish research]. Poznań: Agencja Reklamowo-Promocyjna "Promocja 21".

Kotlarska-Michalska, A. (1997b). Bezpieczeństwo społeczne jako kategoria polityki społecznej i pojęcie socjologiczne [Social safety as a category of social politics and sociological concept]. In: A. Kotlarska-Michalska, T. Rusanen, \& P. Niemelä (eds.), Poczucie bezpieczeństwa społecznego w świetle badań polsko-finskich [Sense of social safety in the light of Polish-Finnish research]. Poznań: Agencja Reklamowo-Promocyjna "Promocja 21".

Kwak, A. (1994). Rodzina i jej przemiany [Family and its transitions]. Warszawa: Instytut Stosowanych Nauk Społecznych UW.

Kwak, A. (2005). Rodzina w dobie przemian. Matżeństwo $i$ kohabitacja [Family in the age of transformations. Marriage and Cohabitation]. Warszawa: Wydawnictwo Akademickie "Żak".

Lichner, D. T., \& Qian, Z. (2008). Serial cohabitation and the marital life course. Journal of Marriage and the Family, 70, 861-878.

Manning, W. D., \& Lichter, D. T. (1996). Parental Cohabitation and Children's Economic Well-Being. Journal of Marriage and the Family, 58, 998-1010.

Maslow, A. H. (1964). Teoria hierarchii potrzeb [The theory of the hierarchy of needs]. In: J. Reykowski (ed.), Problemy osobowości i motywacji w psychologii amerykańskiej [Problems of personality and motivation in american psychology]. Warszawa: PWN.

Maslow, A. H. (1986). W strone psychologii istnienia [Into the direction of the psychology of existence]. Warszawa: Instytut Wydawniczy PAX.

Maslow, A. H. (1990). Motywacja i osobowość [Motivation and personality]. Warszawa: Instytut Wydawniczy PAX.

Mastekaasa, A. (2006). Is marriage/cohabitation beneficial for young people? Some evidence on psychological distress among Norwegian college students. Journal of Community \& Applied Social Psychology, 16, 149-165.

Meyer, T. (1993). Der Monopolverlust der Familie. Vom Teilsystem Familie zum Teilsystem privater Lebensformen. Kölner Zeitschrift für Soziologie und Sozialpsychologie, 45, 23-40.

Mortensen, O., Torsheim, T., Melkevik, O., \& Thuen, F. (2012). Adding a baby to the equation. Married and cohabiting women's relationship satisfaction in the transition to parenthood. Family Process, 51, 122-139.

Nave-Herz, R. (2002a). Über die Gegenwart prägende Prozesse familialer Veränderungen: Thesten und Anti-Thesten. In: H. G. Krüsselberg, \& H. Reichmann. Zukunftsperspektive Familie und Wirtschaft (pp. 133-150). Grafschaft: Vektor-Verlag.

Nave-Herz, R. (2002b). Wanden und Kontinuität in der Bedeutung, in der Struktur und Stabilität
Sense of security in women 
von Ehe und Familie in Deutschland. In: R. NaveHerz (ed.), Kontinuität und Wandel der Familie in Deutschland. Stuttgard: Enke.

Nelicki, A. (1999). „Organizmiczna” koncepcja A. Maslowa [The Organismic theory of A. Maslow]. In: A. Gałdowa (ed.), Klasyczne i wspótczesne koncepcje osobowości (tom 1) [Classical and modern concepts of personality (Vol. 1)]. Kraków: Wydawnictwo UJ.

Niemelä, P. (1997). Pojęcie poczucia bezpieczeństwa i poczucia zagrożenia [The concept of sense of safety and sense of insecurity] In: A. KotlarskaMichalska, T. Rusanen, \& P. Niemelä. Poczucie bezpieczeństwa spotecznego w świetle badań polsko-fińskich [Sense of social safety in the light of Polish-Finnish research]. Poznań: Agencja Reklamowo-Promocyjna "Promocja 21".

Pillsworth, E. G., \& Haselton, M. G. (2005). The Evolution of Coupling. Psychological Inquiry, 16, 98-104.

Platell, A. (2006). Can a career women really be good wife. "Daily Telegraph", Sidney.

Plopa, M. (2005). Psychologia rodziny. Teoria i badania [Psychology of family. Theory and research]. Elbląg: Wydawnictwo Elbląskiej Uczelni Humanistyczno-Ekonomicznej.

Rocznik Demograficzny [Demographic Yearbook] (2012). Warszawa: GUS.

Rhoares, G. K., Stanley, S. M., \& Markman, H. J. (2006). Pre-engagement cohabitation and gender asymmetry in marital commitment. Journal of Family Psychology, 20, 553-560.

Rhoades, G. D., Stanley, S. M., \& Markman, H. J. (2012). The impact of the transition to cohabitation on relationship functioning: Cross-sectional and longitudinal findings. Journal of Family Psychology, 26, 348-358.

Robins, L., \& Regier, D. (1991). Psychiatric disorders in America: The Epidemiologic Catchment Area Study. New York: Free Press.

Rogers, R. G. (1995). Marriage, sex and mortality. Journal of Marriage and the Family, 57, 515-526.

Sampson, R. J., \& Laub, J. H. (1990). Crime and deviance over the life course: The salience of adult social bonds. American Sociological Review, 55, 609-627.

Schneer, J. A., \& Reitman, F. (2002). Managerial life without a wife: Family structure and managerial career success. Journal of Business Ethics, 37, 25-38.

Schneewind, K. A. (1999). Familien - psychologie. Stuttgart: Verlag W. Kohlhammer.

Selzer, J. (2000). Families formed outside of marriage. Journal of Marriage and the Family, 62, 1247-1268.

Slany, K. (2006). Alternatywne formy życia matżeńsko-rodzinnego w ponowoczesnym świecie [Alternative forms of married and family life in the postmodern world]. Kraków: Zakład Wydawniczy - NOMOS.

Stanley, S. M., Rhoades, G. K., \& Markman, H. J. (2006). Sliding versus deciding: inertia and the premarital cohabitation effect. Family Relations, 55, 499-509.

Stanley, S. M., Rhoades, G. K., Amato, P. R., Markman, H. J., \& Johnson C. A. (2010). The timing of cohabitation and engagement: Impact on first and second marriages. Journal of Marriage and Family, 72, 906-918.

Steuden, S., \& Borczon, I. (2002). Koncepcja małżeństwa własnego i obraz małżeństwa rodziców u młodzieży o różnym poziomie poczucia bezpieczeństwa [The idea of one's own marriage and the image of parent's marriage among youth of different levels of sense of security]. In: T. Rostowska, \& J. Rostowski (eds.), Rodzina - Rozwój - Praca [Family-Development-Work] (pp. 37-55). Łódź: WSI.

Szymanowicz, A., \& Furnham, A. (2011). Do inteligent women stay single? Cultural stereotypes concering the intellectual abilities of men and women. Journal of Gender Studies, 20, 43-54.

Uchnast, Z. (1990). Metoda pomiaru poczucia bezpieczeństwa [The method for measurement of the sense of security]. In: A. Januszewski, Z. Uchnast, \& T. Witkowski (eds.), Wykłady z psychologii w KUL (tom 5) [Psychology lectures at KUL (pp. 95-108) (Vol. 5)]. Lublin: Wydawnictwo KUL.

Vaskovics, L. A., Rupp, M., \& Hofmann, B. (1997). Lebensverläufe in der Moderne: Nichteheliche Lebensgerneinschaften. Eine sociologische Längsschnittstudie. Opladen: Leske + Budrich.

Waite, L. J., \& Joyner, K. (1999). Emotional and physical satisfaction in married, cohabiting and dating sexual unions: Do men and women differ? In: E. Laumann, \& R. Michael (eds.), Sex, Love, Health in America (pp. 239-269). Chicago, IL: University of Chicago Press.

Wilmoth, J., \& Koso, G. (2002). Does Marital History Matter? Marital Status and Wealth Outcomes Among Preretirement Adults. Journal of Marriage and the Family, 64, 254-268.

Żurek, A. (2008). Single. Żyjąc w pojedynkę [Singles. Living on one's own]. Poznań: Wydawnictwo Naukowe UAM. 